\title{
Progress in reducing catholic disadvantage in Northern Ireland
}

Link to publication record in Manchester Research Explorer

\section{Citation for published version (APA):}

Li, Y., \& O'Leary, R. (2007). Progress in reducing catholic disadvantage in Northern Ireland. In Proceedings of the British Academy|Proc. Br. Acad. (Vol. 137, pp. 551-589). Oxford University Press.

\section{Published in:}

Proceedings of the British Academy|Proc. Br. Acad.

\section{Citing this paper}

Please note that where the full-text provided on Manchester Research Explorer is the Author Accepted Manuscript or Proof version this may differ from the final Published version. If citing, it is advised that you check and use the publisher's definitive version.

\section{General rights}

Copyright and moral rights for the publications made accessible in the Research Explorer are retained by the authors and/or other copyright owners and it is a condition of accessing publications that users recognise and abide by the legal requirements associated with these rights.

\section{Takedown policy}

If you believe that this document breaches copyright please refer to the University of Manchester's Takedown Procedures [http://man.ac.uk/04Y6Bo] or contact uml.scholarlycommunications@manchester.ac.uk providing relevant details, so we can investigate your claim.

\section{OPEN ACCESS}




\section{Chapter 13 \\ NORTHERN IRELAND \\ Progress in reducing Catholic disadvantage in Northern Ireland \\ Yaojun Li and Richard O’Leary ${ }^{1}$}

\section{CHAPTER SUMMARY}

In this chapter on Northern Ireland our focus is not on ethnic minorities of recent immigrant origin but rather on the indigenous Catholic and Protestant populations who can be viewed as ethno-religious groups. The historically disadvantaged position of the Catholic population continued after the partition of Ireland and the establishment of Northern Ireland in 1921 and the differences with respect to their position in the labour market, especially unemployment rates, have long been a symbol of contention and a matter of political importance. Comparing data from the Continuous Household Surveys in 1985/6 and 2002/3 we find substantial improvement for Catholic men in terms of avoidance of unemployment. This is consistent with the positive impact of the improving economy and the British government's fair employment legislation (Acts of 1976, 1989 and 1998). The class situations of Catholic women have also improved over the period covered. However, we find that Catholic men are still disadvantaged in accessing the salariat and in their labour market earnings. While there is an increase in the absolute numbers of Catholic males working in the professional and managerial posts that make up the salariat in Northern Ireland, relative to Protestant males they are still not achieving a comparable degree of success in gaining access to the salariat.

\section{INTRODUCTION}

In this chapter on Northern Ireland our focus is not on ethnic minorities of recent immigrant origin $^{2}$ but rather on the indigenous Catholic and Protestant populations. The Catholic and Protestant populations may be viewed as ethno-religious groups in the way defined by Anthony Smith (1993), that is, as ethnic groups comprising a named population with a myth of common ancestry, shared culture and group solidarity, and a link with a historic territory or homeland.

The differences between Protestants and Catholics in Northern Ireland with respect to their position in the labour market have long been a matter of political importance. According to Smith and Chambers (1991), the unemployment rates between the two groups were a symbol of contention. A much reported (and apparently enduring) feature was the finding that Catholic men were about two and a half times as likely as Protestant men to be unemployed. Such was the importance of the issue of equality in the labour market that in each of the last three decades the British government has introduced religious equality legislation (Acts of 1976, 1989 and 1998). Bew,

\footnotetext{
${ }^{1}$ Acknowledgement: We would like to thank Dr. Sin Yi Cheung and Professor Anthony Heath for their suggestions on an earlier version of this chapter, and the UK Data Archive for giving us permission to use the Continuous Household Survey data. We alone are responsible for the views expressed, and any errors that might exist in this chapter.

${ }^{2}$ It is estimated that they account for less than 1 percent of the population (Irwin and Dunn, 1997). The 2001 SAR shows that they account for 0.74 of the population (authors' analysis).
} 
Patterson and Teague (1997) comment on the political tensions between the groups on the issue of equality in the labour market with Catholics insisting that more effort be made to address the matter while Protestants feared that affirmative action meant that they were losing out.

Although there has been much previous research and comment on this topic, our chapter can extend the research in the following ways. First, we examine the most recent Continuous Household Survey (2002/2003) data on labour market performance. We compare it with earlier data (1985/1986) to examine change over time. This is of considerable interest given the economic and political changes Northern Ireland has experienced in this period. The improved economic situation generally, including the sharp fall in the rate of unemployment in recent years, might be expected to assist more balance in the ethno-religious situation in the labour market. In addition, the stronger fair employment legislation implemented by the British government in the 1990s, and the major political changes such as the paramilitary ceasefires begun in 1994 and the communal peace deal of 1998 (known as the 'Good Friday' or 'Belfast Agreement'), would give us a reasonable expectation for improvement by 2002/2003 as regards the differences between Catholics and Protestants in the labour market.

A second contribution of this chapter is that we move beyond the sole focus on unemployment which characterized most of the previous research on Northern Ireland. Undoubtedly, unemployment is important and it has been stubbornly higher in Northern Ireland than in the rest of the UK. However, it is not only that Catholics are more likely to be unemployed but-even when employed - they are also less likely to be found in the higher occupations. Therefore, we extend our interest to include the additional question of occupational attainment. This combined focus is particularly appropriate given the relatively big fluctuations from year to year in the overall rate of unemployment at the societal levels vis-à-vis the relative stability of different social groups in the occupancy in the class structures. As we shall soon see, the unemployment rate has fallen substantially in the period covered such that it now affects a much smaller proportion of people, both Catholic and Protestant, than it did nearly two decades ago. Furthermore, the occupational structure has been much improved in Northern Ireland as in the rest of the UK, with a much bigger salariat and a much contracted working class. In this context of substantial improvement in the labour market, it would be of both academic and policy importance to see whether Catholics have caught up with Protestants in terms of both participation in the labour market and of relative positions in the class structure.

Third, this study is designed within the framework of a cross-national comparison. While the requirements of standardisation may limit our research design in some respects, the benefit is that readers will be able to view the Northern Ireland experience with an international perspective where they can assess whether the Catholic experience in Northern Ireland is similar to that of minorities in the other countries, and thereby make some inferences on the effects of national government policies and of macro socio-economic changes.

The historical distinction between the people in Northern Ireland who make up the Catholic and Protestant populations can be traced back to the $17^{\text {th }}$ century. At that time the English government planted with loyal Protestant settlers from Scotland and England lands held by the Gaelic Catholic Irish. The political conflict over land and government between the two groups was given an added intensity because of the religious differences. The disadvantaged position of the Catholic 
population continued after the partition of Ireland and the establishment of Northern Ireland in 1921. Protestant advantage was evident in the labour market and they were especially overrepresented in sectors such as the security forces and the higher levels of the public service, as well as among the skilled labour.

The Protestant population in Northern Ireland is itself made up of numerous denominations. The largest is the Presbyterian Church in Ireland, followed by the Church of Ireland (Anglican) and the Methodists. We have in this chapter put the Protestant denominations into one single religious group. This is justified not only on operational grounds (for the ease of presentation) but on historical grounds. In the last two centuries the political and social divide between the Catholic and the Protestant populations overshadowed any intra-Protestant differences. An illustration of the primacy of the binary distinction is that, in contemporary Northern Ireland, Protestants from the largest Protestant denominations do not refer to marriage between their denominations as intermarriage: they only make that distinction for marriage with Catholics. Persons in Northern Ireland invariably categorise themselves, and are categorised by others, as belonging to the Catholic or the Protestant groups and are treated as such in much of public policy.

Apart from the Catholic and the Protestant distinction in Northern Ireland, there also exists a sizeable, and growing, proportion of the population who would not identify themselves as belonging to any religion or religious denomination. These people are conventionally called 'religious non-identifiers' or 'Nones' for short. This group is often omitted in the analysis of occupational or educational attainment (Cormack et al 1993; Crompton 1995; Gallagher et al 1995; Power and Shuttleworth 1997; Anderson and Shuttleworth 1998; Breen 2003). However, given their distinct characteristics from Catholic and Protestant identifiers (Li 2004), we have decided to include them in the present analysis. ${ }^{3}$

This chapter will focus on the Catholic and the Protestant experience in the labour market between 1985/1986 and 2002/2003 based on the Northern Ireland Continuous Household Survey. ${ }^{4}$ The earlier time points are chosen not only because they provided the earliest available CHS surveys to be compared with the most current ones, but also as they were a time point in the middle of a thirty-year-long conflict. Politically, it marked the introduction of the Anglo-Irish Agreement, a political agreement between the British and Irish governments which heralded a greater focus on equality issues for Catholics within Northern Ireland. It was followed four years later with greatly strengthened labour market equality legislation (the Fair Employment Act, 1989). Methodologically, using the best available government data almost twenty years apart as contained in the CHS ensures comparability in terms of research design, sampling procedure and question wording, which will help us gain a good understanding of the mechanisms for the discrepancies in labour market outcomes between Catholics and Protestants.

\footnotetext{
${ }^{3}$ A question that has remained unanswered is whether Protestants or Catholics are more likely to report "Not Stated/None" in the census returns or social surveys. So far, no data exist to allow such an analysis. The 2001 Census for Northern Ireland contains information on religious denomination and religious background. However, in the newly released 2001 Individual SAR, the variable for community background ('combgn') is defined as "a person's current religious group, if any, or the religious group brought up in for people who do not regard themselves as belonging to any religion” (http://www.ccsr.ac.uk/sars/2001/indiv/resources/01ukind-codebook.pdf). This definition precludes an effective analysis.

${ }^{4}$ See Technical Appendix for more detail on the CHS.
} 


\section{EXISTINg RESEARCH AND PoLiCy INITIATIVES}

Existing research has found that the labour force participation rate of Catholics tends to be lower than that of Protestants, for both men and women. A striking historical characteristic of the Northern Ireland labour market has been the high rate of unemployment as compared with the UK average. Furthermore, the unemployment rate for Catholics has been consistently much higher than for Protestants, especially for men. Catholic men have, in recent decades, typically experienced an unemployment rate almost two and a half times that of Protestant men.

The more detailed occupational profiles and sectors of employment of the two groups exhibit some sharp differences. For example, about 20 percent of males from a Catholic background are employed in the construction industry compared to 12 percent of Protestants (Northern Ireland Census 2001 Standard Tables, S337). Twelve percent of Protestant males work in the public administration, defence and social security sector compared to 7 percent of Catholics (Census 2001 Standard Tables, S337). A striking occupational difference between the religious groups is evident in the security sector, which in 1990 accounted for one in four of all Protestant male public sector workers compared to one in twenty for Catholics (Russell 2004). This sector expanded greatly with the onset of violent conflict.

It is not just in terms of unemployment that Catholics are disadvantaged. Historically Protestants have been better represented than Catholics among the higher social classes. Catholic men are less likely to be found in the professional and managerial classes and more likely to be in the nonskilled classes (Breen and Whelan 1999). Protestants are especially overrepresented in higher levels of the civil service and the police (Sheehan and Tomlinson 1999: 146).

Existing research has also established a number of significant changes in the labour market over the past few decades. The number of persons entering the job market has increased in line with Northern Ireland's growing population. The participation of women in the active labour force has greatly increased. The population of working age grew by 9 percent between 1990 and 2000 (NISRA 2001). Northern Ireland has responded to this with strong growth (13 percent) in employment in the 1990s (McCrudden, Ford and Heath 2004).

In the economy the heavy industries (e.g., shipbuilding) and traditional manufacturing have declined. These were sectors where Protestants were especially overrepresented. On the other hand, the service sector has grown. The sharp growth in public sector employment in the 1970s slowed down in the 1980s and the 1990s.

Coulter (1999) highlights that, prior to the outbreak of the 'Troubles' in 1969, the Catholic middle class was relatively small, but since the 1970s the Catholic middle class has grown remarkably, aided by greater participation in higher education and the expansion of public sector employment. Breen and Whelan (1999) have found some convergence in the class distributions between Catholic and Protestant men although Catholics are still less likely to be found in the professional and managerial classes and are disadvantaged compared to Protestants as regards long-range social mobility. They found convergence in the class distributions for Catholic and Protestant women. 
Notwithstanding the fact that Catholics are still more likely to be unemployed than Protestants, it is generally accepted that there has been substantial improvement in the employment profile of Catholics. Indeed, a more recent observation has been that there are now emerging some areas of employment where Protestants are under-represented, such as the health and education sectors and some local government councils (Russell 2004).

Accounting for differences between Catholics and Protestants in Northern Ireland as regards unemployment or class attainment is both complex and controversial. It is complex because of the range of factors that can be introduced as part of the explanation. These factors include the political structure and its historical legacy, with an emphasis on the macro-level role of the state and intergroup power relations. Other structural factors include the match between the geographical distributions of workers and the available jobs, differences between groups in qualifications, age structure, migration patterns and the traditional higher fertility of Catholic women. Workers or potential workers may experience discrimination or firms may have an associated 'chill factor' which discourages job applications from a particular religious group. Still other factors may include social networks which may serve as 'channels of communication' providing the necessary information to job-seekers about potential job openings (Granovetter 1973, 1995; Portes and Zhou 1993; Portes 1998).

Among the relevant studies examining change over time a declining direct effect of religion has been proposed (Miller 1979, 2004; Miller et al. 1991). Miller (2004) notes the contrast in the findings from his studies of males from the 1970s and the 1990s. Miller (2004: 52) concluded after his analysis of the 1973/4 data that once the other variables in his model had been taken into account, religion continued to have a statistically significant, though weak, direct effect upon occupational status, with Protestants being somewhat more likely to have a higher status occupation. He suggested that this could be interpreted as indirect evidence of religious discrimination affecting Catholics. For the 1996/7 data he reported (2004: 54) that religion did not have a direct statistically significant effect on present occupation once the effects of first job had been taken into account, although it had indirect effects via father's occupation and first job status.

Consistent with the general approach of the international studies in this volume, the approach we adopt here is one that is set within the econometric tradition. Among previous studies which have adopted this approach are studies by Smith and Chambers (1991) and Murphy and Armstrong (1994). We examine the probability that an individual will be found unemployed or situated in a particular class position after taking into account his/her ethno-religious designation and some personal socio-demographic characteristics. A key interest is whether ethno-religious disadvantages remain even after the socio-demographic characteristics are controlled for.

Different approaches tend to reach different conclusions, in part reflecting the factors included in the research design. ${ }^{5}$ Econometric approaches have been criticized for not including some variables. ${ }^{6}$ Econometric approaches are always open to this kind of criticism, as indeed is our

\footnotetext{
${ }^{5}$ See, for instance, Murphy and Armstrong (1994); Gudgin and Breen (1996).

${ }^{6}$ For example, Smith and Chambers (1991) were criticized for not including a variable for the occupational category
} 
study given the requirements in this volume for the cross-national standardization of key explanatory variables and the limits of data at our disposal. We remind the reader that an ethnoreligious penalty in our study is an estimate of the extent to which Catholics are disadvantaged relative to Protestants with the same age, marital status and educational qualifications. Our inclusion of age and education allows us to investigate two of the main explanations that have been offered to account for differences in ethno-religious outcomes in the labour market: demographic explanations and human capital explanations.

\section{Demography}

The demographic explanations tend to focus on population size and age structure. In this regard the Protestants have been numerically larger than Catholics in Northern Ireland. Table 13.1 shows the religious affiliation as reported in the censuses of population between the establishment of Northern Ireland in 1921 and the most recent census in 2001. At the time of the establishment of Northern Ireland, the Catholics comprised about one-third of the population. This proportion has grown in recent decades, although this is less obvious from the 1971 and especially the 1981 censuses of population when there was underreporting of the Catholic population. $^{7}$ The most useful contrast is between 1961 and 1991 where the declared Catholic population increased from 34.9 percent to 38.4 percent while the declared Protestant population (approximated in Table 13.1 by the 'Other Denomination' category) declined from 63.2 percent to 50.6 percent. The most recent census, that for 2001, has the added advantage of allowing us to allocate people by religious background, including the "not stated" and "none" categories. On this basis the Census Office reports that Catholics account for 43.7 percent of the population, Protestants and other Christians 53.1 percent, with 0.4 percent “Other Religions” and 2.7 percent “None” (Northern Ireland Census 2001 Key Statistics).

\section{Insert Table 13.1 about here}

Therefore, the Catholic proportion of the total population has grown over time. Catholics as a group are not only gaining in size, but are younger than Protestants. Twenty-five percent of people with a Catholic background are under the age of 15 as compared with 18 percent of persons of a Protestant background. On the other hand, only 10 percent of Catholics are aged 65 or over, as compared with 17 percent of Protestants (Northern Ireland Census 2001 Standard Tables, S306). This demographic information has two main implications for the study of the labour market. First, it highlights that the growing Catholic population is giving rise to an increased demand for employment by Catholics. Second, demographic change can itself raise tensions within society about the ethno-religious balance.

The Catholics thus have a younger age profile and young people are generally more prone to unemployment. Furthermore, Catholic parents have on average a larger number of children than Protestants. Larger numbers of dependent children have tended to depress participation in employment, especially for women (O’Leary 1998). Overall, with regards to demographic explanations it should also be noted that Catholic disadvantage is a historical feature which predates their recent population growth.

of the security forces.

${ }^{7}$ In 1981 there was an organised boycott of the census. 


\section{Education}

The key role of education has been highlighted among studies conducted on religious group differences (see Osborne 2004, Osborne et al. 1987; Miller et al. 1991). Historically there were differences in the levels of educational attainment of Catholics and Protestants, with Protestants more likely to hold a degree and less likely to leave school without any qualifications. Persons with lesser or no educational qualifications are far more likely to become unemployed or attain low social class positions. Therefore, ethno-religious differences in the level of education could contribute to higher rates of Catholic unemployment and less success in achieving advantaged class positions. Of course, this would still leave open the question as to how those educational differences were produced in the first place. In recent years Catholic educational attainment has been converging with that of Protestants. Furthermore, it has been noted that, even among the higher-educated, there is a higher rate of unemployment among Catholics than Protestants (Osborne 2004:85).

However it is not just the level but also the type of education that has been the subject of research. It has been suggested that some of the Catholic disadvantage in the labour market might be due to the type of education which they receive. Education in Northern Ireland is largely segregated on religious lines with the great majority of Catholics attending Catholicmanaged schools while Protestants attend schools in the state system with an overwhelming Protestant pupil composition. It had been noted that, traditionally, the Protestant pupils in their state schools were more likely than Catholics in their Catholic schools to specialize in scientific and technical subjects. This lesser participation in science-related subjects was noted in the 1970s (Osborne and Murray 1978) and was still observed thirty years later (Osborne and Shuttleworth 2003). This could give Protestants an advantage in the labour market; however, as Bew, Patterson and Teague (1997:127) point out, any such differences should be increasingly irrelevant in the contemporary Northern Ireland labour market where the traditional manufacturing sector has declined.

The level of education is thus widely accepted as a key explanatory variable in labour market outcomes. Apart from the main effects of education, we should also be alert for possible interaction effects between particular ethno-religious groups and levels of education-to show, for instance, whether Catholics receive lower returns on their educational qualifications.

The demographic and education factors should also be viewed in the context of educational expansion and population migration. In recent decades there has been a preference for Protestant students to leave Northern Ireland to obtain university education in Britain. Protestants form the majority of those university students migrating from Northern Ireland (Osborne et al. 1987). Research has indicated that most of the migrating students are not returning to Northern Ireland upon completion of their education, thereby reducing the competition from Protestant graduates for jobs there (Miller et al, 1991).

Turning now to the issue of class, the lower class profile of Catholics could also make them more vulnerable to unemployment. However, other researchers have noted that even among professional or managerial workers, Catholic men are more likely to be unemployed than Protestants (Smith and Chambers 1991: 166). For some specific occupational categories, 
unemployment can be particularly high, as was the case in the 1980s for construction workers, an industry in which Catholics are traditionally overrepresented (Smith and Chambers 1991).

Previous research has concentrated on the relative disadvantage of Catholic men compared to Protestant men, commenting that the gap appears much smaller for women and noting that fewer women are active in the labour market than men. Our study includes an examination of the labour market position of women. Women's work careers have been more disrupted by breaks due to childrearing responsibilities than has been the case for men and Catholic women tend to have more children. There is also a tendency for women to underreport their unemployment (McLaughlin 1993). As we shall see, there has been a growth in the economic activity of women in the recent decades, and this has been related particularly to the public service sector (Coulter 1999). Catholic and Protestant women are usually found in different occupational categories and sectors with Catholic women disproportionately employed in the health and social services.

In sum, higher levels of unemployment among Catholics compared to Protestants have been a persistent feature of the Northern Ireland labour market, especially for men. These have not been convincingly accounted for by the demographic, educational or occupational characteristics of the Catholic population. A key plank of the British government's response to the ethno-religious penalty has, since 1976, been the introduction of fair employment legislation and monitoring aimed at equal labour market outcomes for the two groups. The next section gives a brief account of these state-sponsored initiatives.

\section{Policy Initiatives}

The Fair Employment (Northern Ireland) Act 1976 outlawed discrimination in employment on grounds of religious or political beliefs. A Fair Employment Agency was set up to promote fair employment practices. It had advisory and limited investigative and enforcement functions (Bew, Patterson and Teague 1997). However, the 1976 Act and the Agency were criticized for being ineffective and in the 1980s pressure mounted on the British government to introduce stronger legislation.

The Fair Employment (Northern Ireland) Act 1989 extended the number of workplaces which had to register with the new Fair Employment Commission (FEC). It required all private companies with more than ten employees who work more than sixteen hours a week to register. All public sector employers were already required to be registered. The registered employers were required to report annually to the FEC the religious composition of their workforce. It increased the level of monitoring in that all the public sector employers and those in the private sector who had more than 250 employees had to report to the FEC on the ethno-religious backgrounds of the job applicants and those appointed. In support of the legislation, government departments were to ensure that they only awarded contracts to firms which complied with the FEC requirements. A new Fair Employment Tribunal was established to adjudicate on individual claims of discrimination.

The FEC expected employers to make progress over time in matching the ethno-religious composition of their workforce with that of the relevant employment catchment area. Voluntary affirmative action measures were encouraged but employers could also be directed by the Commission to undertake affirmative action. The type of affirmative action set out often 
involved the setting of goals and timetables to measure progress but did not include setting down quotas (Bew, Patterson and Teague 1997).

In 1999, in the aftermath of the Good Friday Agreement, the Equality Commission for Northern Ireland replaced the FEC, with an enhanced remit. The Fair Employment Monitoring

Regulations (NI) 1999 extended monitoring to internal applications and appointments and more significantly for the first time has sought employer returns on promotees (for employers of 251 or more persons). Given these strengthened fair employment measures it is reasonable to expect some improvements as regards the ethno-religious balance in the labour market.

\section{Labour MARKet Situation Of CATHOLICS AND Protestants (1985/1986 - 2002/2003)}

We now turn to the heart of our analysis: comparing the labour market situations of Catholics and Protestants over two decades. We analyse labour market situations in terms of participation rates, unemployment risks and class positions, and we do this for men and for women separately. As noted earlier, the data sources used are the Northern Ireland Continuous Household Survey (CHS), the equivalent of the General Household Survey for Britain (used by Cheung and Heath in this volume). It is noted here that even though the CHS is the standard government survey and the best possible data source for our present purposes, the sample sizes for individual years are still insufficient for the analysis at hand, due chiefly to the constraints imposed in this volume for international compatibilities (e.g., including only individuals aged 18-59). We thus combined the data for 1985 and 1986 and the data for 2002 and 2003. ${ }^{8}$

\section{Labour market participation}

Before we proceed to the thrust of our analysis, we need to examine briefly changing educational profiles of Catholics and Protestants. We observed earlier that Catholics historically tended to have lower levels of educational qualifications and that these qualifications were also less rewarding in terms of labour market attainments. It is thus of importance to examine how their profiles of educational qualifications have changed over the period of interest and what implications that might have for labour market situations.

\section{Insert Tables 13.2 about here}

The data in Tables 13.2 show a very important feature of convergence between Catholics and Protestants in terms of educational attainment. Over the past two decades, the differences between the two groups have been sharply reduced, especially for men. In the earlier period, Protestant men were almost twice as likely as Catholic men to have higher tertiary (first degree or above) qualification (6.9 percent and 3.7 percent respectively), and the former were also more likely than the latter to have lower tertiary (professional qualifications below degree, such as teaching and nursing) qualifications (17.7 percent and 12.6 percent respectively). Combining the two tertiary figures, we can see that nearly a quarter of the Protestant men (24.6 percent) had tertiary education, 8.3 percentage points higher than the Catholic men. If we look under the column for 'Primary/None', we find that well over half (58.7 percent) of the Catholic men had only primary or no formal educational qualifications, a figure 12 percentage points higher than that for the Protestant men. However, looking at the data for 2002/2003, we see that the

\footnotetext{
${ }^{8}$ See Technical Appendix for more detail.
} 
Protestant lead has been largely reduced; Catholic men have caught up with their Protestant counterparts at almost every level of education.

The differences between Catholic and Protestant women were not as polarized as those between Catholic and Protestant men, even in the earlier period. In fact, we find very little difference between Catholic and Protestant women in terms of higher and lower tertiary qualifications in the 1985/1986 period. The differences were mainly in the higher secondary (A-Levels or equivalent) and the "Primary/None" categories. The Protestant women were more likely to have higher secondary and less likely to have no qualifications than Catholic women in the earlier period. Yet by 2002/2003, the religious group differences are barely discernible at each of the five levels. It is also noteworthy that the 'Nones' were quite highly educated.

Given their respective educational profiles, we may expect marked differences in the labour market outcomes between Catholics and Protestants in the earlier period-for men in particular. The data would also suggest, however, that no such differences will persist in the later period. With this in mind, we now turn to our main analysis. Our samples are restricted to men and women aged 18 to 59 and resident in Northern Ireland at the time of interview. We start with the economic activity rates among the targeted populations, then move to the labour market positions among the economically active, and finally come to the class positions among the employed. At the each level of our analysis, we shall explore where differences lie and what possible factors could account for the differences.

\section{Insert Tables 13.3 about here}

The data in Tables 13.3 show the labour market participation rates for Catholic and Protestant men (13.3A) and women (13.3B) in 1985/1986 and 2002/2003. Here we get our first glimpse of the Catholic disadvantage. For both sexes alike, and at both time points, Catholics were less likely to be economically active than Protestants. For instance, in 1985/1986 Catholic men were 4.4 percentage points behind Protestant men in terms of active labour market participation, and in 2002/2003, the figure is even higher at 5 points. The differences for women are much bigger. In the earlier period, Catholic women were 11 points behind their Protestant counterparts; in the later period, the figure has decreased somewhat but remains high at 7.4 points. It is also notable in the context that the 'Nones' were, as compared with the other two groups, more likely to be students.

If Catholic disadvantage is exemplified in lower participation rates, a related question is, then, where do the main differences among the economically non-active lie? Here we remind the reader that we are dealing with a population of working age (18 to 59). A closer look at Table 13.3A shows that, among men, Catholics were more likely to be found in the 'other inactive' group. Since these respondents were not of a legal retirement age, the most probable situations in this group are the disabled, long-term sick or discouraged workers who had opted for early retirement. Amongst women we do not find much difference between the two main groups with regard to their membership in the 'other inactive' category; rather the main difference lies in the category of 'looking after home'. As we noted earlier, Catholics, by tradition and culture, tend to have more children and hence larger families (especially true in the 1985/1986 period). Here we find that nearly half (46 percent) of Catholic women were 'looking after home' in 1985/1986, 
compared with 35 percent of Protestant women, a difference of 11 percentage points. In this regard, the difference was halved in the later period (to 5.6 points), reflecting the fact that both Catholics and Protestants now have smaller families than some twenty years ago as well as that more women are now economically active even when they have children.

Labour market situations of the economically active

Looking at the differences in the participation rates is only a first, albeit very important, step. There are pronounced differences among the economically active as well, to which we shall pay particular attention in the following analysis. We shall first look at the differences among the economically active (i.e., among those who are working or seeking work) and then look at the class positions among those who are working (i.e., omitting those who are unemployed). It is thus the case that at each further step in our analysis we are narrowing down our focus by including a smaller sample. The aim of this procedure is to highlight the patterns and the trends of social differences between Catholics and Protestants in the most important aspects of their labour market situations, and to explore the mechanisms whereby such differences are brought about.

\section{Insert Tables 13.4A and 13.4B about here}

The data in Tables 13.4A and B show the occupational and unemployment distributions positions among the economically active. In both tables, we find marked disadvantages for Catholics in the earlier period and much reduced differences between the two groups in the later period. For instance, in the earlier period a staggering 36.4 percent of the Catholic men were unemployed, roughly two and half times as many as amongst Protestant men (15.3 percent). Although the difference is less than amongst men, Catholic women were also more likely to be unemployed than Protestant women (14.5 percent vs. 10.3 percent). In 2002/2003, the general economic situation was much improved and the overall unemployment rate was much lower than in 1985/1986. However, we still find Catholics more likely to be unemployed than Protestants, around 2 points for men and 1.4 points for women. This data thus suggests that Catholics bore the brunt of economic hardship when unemployment ran rampant in society and that the social inequality still remains even in a much ameliorated socio-economic context. It is, however, also the case that the enduring theme of ' 2.5 times' in terms of unemployment, as was much commented upon in the earlier research, is not found in the most recent data. It is also the case that in the earlier period, Protestant men were much more likely to be in the 'white-collar' (salariat or routine non-manual) or supervisory positions than Catholic men.

As Table 13.4 also shows, with regard to class positions we again find that the Catholics have been disadvantaged, although this disadvantage has been reduced over time. At the earlier time point, the Catholic disadvantage was mainly found in their higher likelihood of working within semi- or unskilled manual jobs (if we re-percentage in order to exclude the unemployed the figures are 20.6 percent vs. 16.3 percent for men and 42.5 percent vs. 36.3 percent for women). Catholic men were also less likely to have professional or managerial jobs (22.8 percent vs. 28.6 percent for Protestant men when re-percentaged). In 2002/2003, the differences in terms of access to the salariat and the semi- and unskilled manual working class were, while still visible, much reduced. As the data show, by this later time period, Catholic women were actually more likely to be found in the salariat than Protestant women. 
A final comment in this section relates to self-employment. It has been suggested that ethnic minorities tend to seek self-employment as a strategy to avoid discrimination in the charter labour market (Clark and Drinkwater 1998). We find few signs of such strategy, either in Table 13.4 or in our modelling tables (Appendix Table 13.1A). At neither time point were Catholic men more likely to be self-employed than Protestant men, nor Catholic women more so than Protestant women. ${ }^{9}$

\section{Unemployment: Ethno-Religious Penalties in ACCEssing the LABour MARKeT}

Having discussed the patterns and trends at the descriptive level, we now turn to statistical modeling. The descriptive data give us the broad profile of Catholic disadvantage, but not the net effects due to ethno-religious statuses after controlling for age, education and marital status, all of which are likely to affect labour market outcomes between different social groups. As with other chapters in this volume, we measure ethno-religious penalties by the extent to which ethnoreligious minorities (in this case Catholics) are disadvantaged in comparison with the majority group (in this case Protestants) of the same age, educational qualification and marital status. There are other variables which have been included in other studies and which we could control for but have not, as our analysis is shaped by considerations of cross-national comparison. For example, type of industry, geographic areas, number of children and social networks could all be expected to impact on labour market situations in Northern Ireland but are not included in the analyses below. ${ }^{10}$

Specifically our analysis focuses on two aspects of labour market outcomes: avoidance of unemployment and access to the salariat (as opposed to semi- or unskilled manual working class). These two aspects can be seen as referring to 'economic exclusion' and 'economic inclusion' respectively. To see the patterns and trends more clearly, we shall present the data for the two periods separately, and also in a combined form ('pooled data') which will help us analyse the trends. Separate analyses are presented for men and women. In Tables 13.5 (A and B), we present results for three sets of data: (1) data for the earlier period (1985/1985), (2) for the later period (2002/2003) and the pooled data (all four years). In each set, we conduct two models. In Model 1, we control for age, ethno-religious status, education and marital status. In Model 2, we add interaction effects with education, to test whether Catholics obtain similar returns to their educational qualifications. In the pooled data, we also control for the interaction effects of Catholics in the later as opposed to the earlier period, to check for change over time.

\section{Insert Tables 13.5A and 13.5B about here}

Data in Tables 13.5A and B show the results of logistic regression on the avoidance of unemployment for men and women respectively, with negative coefficients indicating a higher

\footnotetext{
${ }^{9}$ One possible explanation for the difference between our finding and that by Clark and Drinkwater is that Catholics in Northern Ireland do not see themselves as 'ethnic minorities' in the same way or to the same extent as, say, Indians or Chinese do in Britain, and hence do not seek self-employment as an economic enclave as actively as do ethnic minorities in other societies.

${ }^{10}$ However, it is noted that Smith and Chambers argue that type of industry and locational factors 'do very little to explain the difference in the unemployment rate between Protestant and Catholic men’ (1991: 175).
} 
likelihood of unemployment. Let us first look at the data for men in Table 13.5A. In 1985/1986, we find significant effects for age, education and marital status, mostly in the expected directions. ${ }^{11}$ With regard to age, there is also a significant curvilinear relationship, suggesting that unemployment tends to be high amongst the young, declines as people reach occupational maturity, and starts to increase again as people approach retirement. Education, as expected, helps people find and stay in employment. Married people are also more likely to be in jobs than the single or the divorced/separated. Yet, controlling for the effects of age, education and marital status, Catholics were still found to be significantly less likely to be in employment than Protestants.

As we noted earlier, existing research (Osborne 2004) shows that Catholics are more likely to be unemployed than Protestants, even when highly educated. Our initial results corroborated this finding when three-way tables were analyzed. ${ }^{12}$ However, as Model 2 shows, when age and marital status are included in the models as covariates, we find no significant interaction effects between Catholics and education. Thus, as indicated in the main effects, Catholic men are, at each level of education, less likely than Protestant men to avoid unemployment. Judging by the magnitude of the coefficients, education and ethno-religious status have the more pronounced effects.

In the 2002/2003 data, no significant differences were found between the two groups after age, education and marital status were taken into consideration, even though further analysis did show that Catholics were still significantly more likely to be unemployed than Protestants when no other factors were taken into account. ${ }^{13}$ These analyses indicate that age, marital status and the lack of educational qualifications largely account for employment status. Finally, the pooled data show that Catholic men were on the whole disadvantaged as compared to Protestant men, that the overall employment situation had significantly improved by 2002/2003, and that the Catholics (as well as Protestants) benefited from this improvement.

The patterns in Table 13.5B show that, among economically active women, it is educational qualifications and marital status that mainly account for differences in avoidance of unemployment. At neither time point were there any significant differences between the Catholic and Protestant probabilities when the other variables were included in the model. ${ }^{14}$ In the analysis of the pooled data, we find that Catholic women were disadvantaged to some extent

\footnotetext{
${ }^{11}$ We find an unexpected feature here in that men with lower secondary qualifications were significantly more likely to be in employment than those with higher secondary qualifications. Further analysis shows that of the 335 Protestant men with higher secondary qualifications, 49 (14.6 percent) were unemployed, as compared with 9.4 percent of Protestant men with lower secondary qualifications. No such 'anomalies' are found for Catholic men in 1985/1986, or for women at either time point.

${ }^{12}$ Data not presented, but available on request.

13 The Catholic men had log-odds of -.31 in terms of avoidance of unemployment in 2002/3 as compared with Protestants, which is significant at the 0.05 level. It is noted here that the coefficient for the interaction effect of 'Catholic qualifications' was quite strong (at .24), which is significant at the 0.10 level.

${ }^{14}$ Further analysis shows that when no other variables are included, Catholic women were significantly less likely than Protestant women to have a job at the 0.01 and 0.10 levels respectively at the two time points.
} 
(significantly in Model 1 where no interaction effects were included ${ }^{15}$ ). Comparing the patterns for men and for women, we find that education and age play a more important role for men whilst marital status plays a more important role for women.

\section{Occupational Class: Ethno-Religious Penalties in the Labour MARKet}

Turning now to occupational class positions among the employed (Tables 13.6A and B), we report results from multinomial logit regression models where each of the other class categories (as shown in Tables 13.4) is contrasted with the semi- and unskilled working class. Four such contrasts are obtained. However, for the ease of presentation and in terms of theoretical importance, ${ }^{16}$ we only report the results comparing access to the salariat with access to the semiand unskilled working class. The data on the other contrasts are shown in Appendix Table 13.1A.

\section{Insert Tables 13.6A and 13.6B about here}

The data for men in Table 13.6A show that, in the competition for access to the most advantaged professional and managerial positions (salariat) and for avoidance of the least advantaged positions of semi- and unskilled working class, Catholics were disadvantaged compared to Protestants at both time points. In 1985/1986, Catholics were significantly less likely to be in the salariat than Protestants. ${ }^{17}$ The data also make evident that educational qualifications were of crucial importance in helping people gain access to the salariat and, as Table 13.2 showed, Protestants were on the whole better qualified than Catholics. Model 2, however, shows that even similarly qualified Catholics do not fare equally well in the competition for salariat positions. Compared with Protestant men of the same age, educational qualification and marital status, Catholic men in 1985/1986 were estimated to have only slightly better than a 50 percent chance of being in the salariat rather than in the semi- and unskilled working class. ${ }^{18}$

We might have expected from Tables 13.2 and 13.4 that, as a result of the convergence in educational attainment, the class disparities between the two groups would have leveled off by 2002/2003. However, the data for 2002/2003 show that Catholic men remained significantly less likely than their Protestant counterparts to gain access to salariat positions, and this feature

\footnotetext{
${ }^{15}$ With large samples, it is easy to detect even relatively small differences. However, we notice that the coefficients for Catholic women in all the models in the table were negative, suggesting that Catholic women were on the whole disadvantaged as compared with Protestant women with regard to employment opportunities.

${ }^{16}$ Insofar as social equality is concerned, it can be argued that it is the competition in this regard rather than that in gaining access to routine non-manual, petty bourgeoisie, foremen and manual supervisors, or skilled working class versus semi/unskilled working class positions that has much greater impact on people's life chances and life choices (Goldthorpe 1987; Heath 1981).

${ }^{17}$ With no other factors controlled for, Catholic men are less likely than Protestant men to be in salariat. The log odds are -.46 and -.25 at the two time points respectively, which are significant at the 0.001 and 0.05 levels. It is also noted that as no male graduates were found in the semi- and unskilled working class in the earlier period, we randomly added one such case for Protestant and one such case for Catholic in the dataset so as to reduce the effects of full tertiary education on the salariat versus unskilled contrast.

${ }^{18}$ Calculated as $\mathrm{e}^{-.56}=.57$.
} 
obtains whether or not we control for the interaction effects of Catholic education. For instance, the log coefficients for Catholic men were -.36 and -.42 under the two models, both significantly different from zero. The evidence from the combined dataset also suggests that Catholic men were still lagging behind their Protestant counterparts in 2002/2003. However, we should also note that the Catholic ethno-religious penalty did decrease from -.56 in the earlier period to -.42 in the later period, suggesting that some progress may have been made.

The models for employed women, in Table 13.6B, show three main features. First, no significant differences between Catholics and Protestants existed as regards salariat attainment rather than semi- and unskilled manual positions. This is the case whether we look at the data for the earlier or the later period, or for the pooled data. Second, at both time points (in contrast to men) higher educational qualifications have disproportionately helped Catholic women, Catholic women obtaining higher returns on their educational investments than did Protestant women. In the later period, the effects were even significantly so. Third, the patterns in the pooled data show no sign of improvement for Catholic women in 2002/2003 (the interaction term between period and religion falling well short of statistical significance).

\section{Insert Figure 13.1 about here}

In order to understand the patterns more clearly, we show the fitted probabilities of access to the salariat for men and women, by educational levels, for both time periods in Figure 13.1. Three features emerge. First, at both time points, Protestant men were somewhat more likely than Catholic men to be in the salariat, especially with full secondary and lower tertiary levels of education. For women, however, ethnic differences were barely visible. This feature seems to suggest some level of ethnic penalty for Catholic men. Second, it is also the case that the greatest determinant of access to the salariat (by far) was education and not ethno-religious group. Thus Catholic men with degrees were much more likely to be in the salariat than Protestant men without degrees. Third, as women salariat members are usually found in the lower rather than the higher grades (Heath and McMahon 1997; Li 2002), lower tertiary education has a much stronger effect on women in their access to the salariat than on men.

Finally this section will conclude with a brief look at earnings differentials between the two groups. Earnings data are collected in the $\mathrm{CHS}^{19}$ just as in the GHS. In this chapter, we shall use predicted values of total annual gross earnings from the labour market as our dependent variable, controlling for class, education, religion, age, age square and marital status. Like Cheung and Heath (Chapter 12 of this volume), we calculate the earnings profiles of certain class/educational groups, such as salariat with full tertiary education, skilled workers with full secondary education, petty bourgeoisie with lower secondary education and semi- and unskilled working class with only primary or no formal education. The findings are shown in Figure 13.2.

\section{Insert Figure 13.2 about here}

The earnings of the Protestant salariat were set as 100 percent and all other groups were compared with them. For men and women alike at both time points, salariat with full tertiary

\footnotetext{
${ }^{19}$ See Technical Appendix for more detail.
} 
education had, as expected, higher earnings than did less educated groups in lower social classes. The differentials are more noticeable in the later period (2002/2003) than the earlier period (1985/1986). As our main focus is upon the differences between the Protestants and the Catholics, we find that for men in the lower social positions and for women, there is hardly any difference between the two groups. Yet for men in the salariat with degrees, Catholic disadvantages are quite clear. In the earlier period, a Protestant man in the salariat and with a degree was predicted to earn $£ 1,268$ per annum more than his Catholic counterpart of the same age and marital status. ${ }^{20}$ In the later period, the differential was $£ 2,021 .^{21}$ In other words, a Catholic man in the salariat and with a degree was earning 89.2 percent (in 1985/1986) and 92.5 percent (2002/2003) of what his Protestant counterpart earned. A Catholic woman in the salariat and with a degree earned less (95.5 percent) in the earlier period than her Protestant counterpart, but slightly more (103.4 percent) in the later period. Thus in earnings, as in access to the salariat, disadvantages remained for Catholic men.

One caveat regarding this analysis: We should point out that our earnings data do not necessarily show that Catholic men in the same job grades and with the same work experience were paid less than their Protestant colleagues. The salariat as a class is a broad group and, owing to data limitations, our analysis did not differentiate between, for example, the higher and the lower grades within the class (see Goldthorpe 1987; Savage et al. 1992; Li 1997, 2002; and Breen 2003 for further discussion). ${ }^{22}$ It could well be that Catholics are employed in lower-level jobs within the salariat and have yet to penetrate the higher echelons to the same extent as Protestants. Further research with more complete data sets may be needed to address the issue of equal pay more completely.

\section{DisCUSSION AND CONCLUSION}

This chapter has used the Continuous Household Survey (CHS) to analyse patterns and trends of labour market activity for Catholics and Protestants aged 18 to 59 in Northern Ireland. This is a solid data source and our variables are all standardized. We shall give a brief summary of our findings here.

At the broadest level, Catholic disadvantage is shown in their lower rates of participation. The patterns were nearly constant between 1985/1986 and 2002/2003: Catholic men were less likely to be economically active and more likely to be inactive at both time points, whilst Catholic women were more likely to be in home duties, especially in the earlier period.

At each further level, we find Catholic men and women more likely to be unemployed, to be in the semi- and unskilled working class, and less likely to be in the salariat. However, we also find

\footnotetext{
${ }^{20}$ Calculated as $£ 11,732-10,464$.

${ }^{21}$ Calculated as $£ 26,921-24,900$.

${ }^{22}$ Using the newly released samples of anonymised records from the 2001 Census for Northern Ireland, we find that Catholic men, but not women, are still behind Protestant men in gaining access to the higher grades of the salariat (6.7 percent and 8.2 percent respectively). Even among the highly educated (qualification level 5), Catholic men are 5 percentage points behind their Protestant counterparts (30.7 percent and 35.6 percent respectively) in being found in Class I of the salariat.
} 
that the longstanding and widely reported feature of ' 2.5 times' difference in unemployment rates of Catholics and Protestants is present for men only in the earlier, but not the later, period. Therefore, we find significant improvement for Catholic men in terms of avoidance of unemployment from 1985/1986 to 2002/2003. However, this is a recent development and, as such, we do not know if it marks a permanent shift or one which might be undermined by any economic downturn and the operation of 'last in/first out' redundancy policies. Nevertheless, it is an important development, which may be due to a combination of factors, including the improved economic environment and the operation of fair employment legislation. Our analysis points to the fact that unemployment rates may fluctuate from year to year, frequently beyond the control of individual firms (or even the government), and hence may not be effectively used as a 'golden rule' of fairness and equality. The relative position within the class structure is, in our view, a more effective indicator of social equality. Indeed, the fall in the overall level of unemployment and the reduced educational difference between the religious groups may herald a revised policy focus. Our own results suggest what that focus could be-Catholic male disadvantage as regards attaining high social class positions.

Even though we find significant improvement for Catholics in terms of avoidance of unemployment (for men) and class situations (for women) over the period covered, we still find that Catholic men are substantially disadvantaged in accessing the salariat and in their labour market earnings. This occurs in spite of the overall improved class structure in Northern Ireland and improvements in their educational attainment, now almost parallel to that achieved by Protestant men. While there may be an increase in the absolute numbers of Catholic males working in the professional and managerial posts that make up the salariat in Northern Ireland, relative to Protestant males they are still not achieving a comparable degree of success in gaining access to the salariat, and in particular to the higher grades of the salariat.

However, it is also important to take note in this context that, in spite of the disadvantages experienced by the Catholic men in the period as covered by our data, our analysis does show that progress has been made, both in accessing the salariat and in their annual earnings from the labour market. Whilst equality is still a goal to strive for, these achievements cannot be dismissed. Another important point to note here is that as our analysis in this chapter is geared towards international comparison, our selection of explanatory variables may well be different from that in other studies and, as such, our results may be different from those of other scholars concerned with similar issues.

How, then, do we explain these findings and what are the policy implications? It may be that improvement as regards exiting unemployment can be affected in a shorter time period than accessing the salariat. Furthermore, more Catholics in employment may bring to their careers the disadvantage of a labour market history marked by earlier periods of unemployment. However, we return to the policy matter of the operation of fair employment legislation.

An examination of the fair employment legislation and monitoring procedures in Northern Ireland shows that they have been designed for redressing religious group differences in unemployment. For most of the period covered in our study, the Fair Employment Commission has been active in monitoring and advising on fair recruitment. Indeed a review by the Standing Advisory Commission on Human Rights (SACHR 1997) on the impact of the 1989 legislation 
even concluded that for the monitored workforce there is 'no evidence that either community is experiencing systematic discrimination at the point of selection'. Another study of the fair employment agreements adopted by employers concluded that they effected an improvement in fair employment (McCrudden, Ford and Heath 2004: 123 n2).

However, it is only in the aftermath of the 1998 Good Friday Agreement that the Fair Employment Monitoring Regulations (NI) 1999 extended monitoring to internal applications and appointments and more significantly for the first time has sought employer returns on promotees (for employers of 251 or more persons). Information on promotees is provided for the year 2001 and subsequent years. Given our results on access to the salariat, this would seem to be a timely development. It may also be part of the explanation for the discrepancy in our findings regarding the different levels of progress on unemployment and class attainment.

It is sometimes difficult to resist the temptation to regard Northern Ireland as a place where little ever changes. Differences between the religious groups in their relative chances of unemployment have been a longstanding and contentious feature of Northern Ireland society. However, our results uncover a significant change that substantial progress has been made between 1985/1986 and 2002/2003 as regards religious differences in avoidance of unemployment. We also confirm the growth in the size of the Catholic middle class. Our attention is instead directed to a somewhat less publicly visible outcome, namely access to the salariat and earnings from the labour market where Catholic male disadvantage still exists even though some progress has been observed. This disadvantage will pose a challenge to the society generally and to the fair employment body in particular. At the societal level, the young, educated, Catholic population is continuing to increase in a political environment where their expectations of equality are affirmed by the Good Friday Agreement. This is at a time when Protestants are reported as starting to have concerns about their position in the workplace (Equality Focus 2004). The success of affirmative action agreements in reducing religious segregation within firms has been noted, yet these less segregated firms will be the sites for increased competition for promotion between the religious groups. If the fair employment legislation is effective, and many commentators conclude that it is, then in time it may also have an impact on improving the access by Catholic males to the salariat. 


\section{REFERENCES}

Anderson, J. and Shuttleworth, I. (1998). Sectarian demography, territoriality and political development in Northern Ireland, Political Geography, 17, 187-208.

Bew, P., Patterson, H., and Teague, P. (1997). Between War and Peace, London: Lawrence and Wishart.

Breen, R. and Whelan, C. (1999). Social Mobility in Ireland: A comparative analysis. In Heath, A., Breen, R. and Whelan C. (Eds.) Ireland North and South, Oxford: Oxford University Press, pp. 319-39.

Breen, R. (2003). Is Northern Ireland an Educational Meritocracy? Sociology, 37, 657-75.

Clark, K. and Drinkwater, S. (1998). Ethnicity and self-employment in Britain, Oxford Bulletin of Economics and Statistics, 60, 383-407.

Cormack, R.J., Gallagher, A.M. and Osborne, R.D. (1993). Fair Enough? Religion and the 1991 Population Census, Belfast: Fair Employment Commission for Northern Ireland.

Cormack, R. and Osborne R. (Eds.) (1983). Religion, Education and Employment: Aspects of Equality of Opportunity in Northern Ireland, Belfast: Appletree.

Compton, P. (1995). Demographic Review Northern Ireland, Belfast: Northern Ireland Economic Development Office.

Compton, P. (1989). Fertility and Family Planning in Northern Ireland, Aldershot: Avebury.

Coulter, C. (1999). Contemporary Northern Irish Society, London: Pluto.

Equality Focus (2004). Issue 2, Autumn, Belfast: Equality Commission.

Gallagher, A.M., Osborne, R.D. and Cormack, R.J. (1995). Fair shares? Religion and the 1991 Population Census, Belfast: Fair Employment Commission for Northern Ireland.

Goldthorpe, J. H. (with Llewellyn, C. and Payne, C.) (1987). Social Mobility and Class Structure in Modern Britain, Oxford: Clarendon Press.

Granovetter, M. S. (1973). The strength of weak ties. American Journal of Sociology, 78, 136080.

Granovetter, M. S. (1995). Getting a Job: A Study of Contacts and Careers, $2^{\text {nd }}$ edition, Cambridge, MA: The University of Chicago Press.

Gudgin, G. and Breen, B. (1996). Evaluation of the ratio of unemployment rates as an indicator of fair employment, Queens University of Belfast: Central Community Relations Unit. 
Heath, A. F. (1981). Social Mobility, London: Fontana.

Heath, A. F. and McMahon, D. (1997). Education and occupational attainments: the impact of ethnic origins, in Karn (Eds.) Ethnicity in the 1991 Census, London: The Stationery Office, pp. 91-113.

Irwin, G. and Dunn, S. (1996). Ethnic Minorities in Northern Ireland, Coleraine: Centre for the Study of Conflict, University of Ulster.

Li, Y. (1997). The Service Class: Theoretical Debate and Sociological Value, D.Phil Thesis, Nuffield College, Oxford University.

Li, Y. (2002). Falling off the ladder? Professional and managerial careers, European Sociological Review, 18, 253-70.

Li, Y. (2004). Samples of Anonymised Records (SARs) from the UK Censuses: A Unique Source for Social Science Research, Sociology, 38, 553-72.

McCrudden, C., Ford, R. and Heath, A. (2004). The Impact of Affirmative Action Agreements. In Osborne, B. and Shuttleworth, I. (Eds.) Fair Employment in Northern Ireland: A Generation on, Belfast: Blackstaff Press.

McLaughlin, E. (1993). Unemployment. In Kremer, J. and Montgomery, P. (Eds.) Women's Working Lives, Belfast: HMSO.

Miller, R. (2004). Social Mobility in Northern Ireland: Patterns by Religion and Gender. In Osborne, B. and Shuttleworth, I. (Eds.) Fair Employment in Northern Ireland: A Generation On, Belfast: Blackstaff Press.

Miller, R., Curry C., Cormack R., and Osborne, R. (1991). The Labour Market Experiences of an Educational Elite: A Continuous Time Analysis of Recent Higher Education Graduates, Coleraine: University of Ulster.

Miller, R. (1979). The Occupational Mobility of Protestants and Catholics in Northern Ireland, Belfast: Fair Employment Agency.

Murphy, A. with Armstrong, D. (1994). A Picture of the Catholic and Protestant Male Unemployed, Belfast: Central Community Relations Unit.

Northern Ireland Census 2001-Standard Tables. (2003). Norwich: TSO

Northern Ireland Census 2001- Key Statistics (2002) Belfast Stationery Office.

Northern Ireland Continuous Household Survey (CHS) for 1985, 1986, 2002 and 2003. http://www.data-archive.ac.uk/findingData/ghsTitles.asp (last accessed 14/9/05). 
O’Leary, R. (1998). Female Workers on long-term sickness benefit in the Republic of Ireland: The relevance of their relationship with the labour market, Social Policy and Administration, 32, 245-62.

Osborne, R. (2004). Education and the Labour Market. In Osborne, B. and Shuttleworth, I. (Eds.) Fair Employment in Northern Ireland: A Generation On, Belfast: Blackstaff Press.

Osborne, R. and Shuttleworth, I. (2003). Potential Skills Shortages in the Northern Ireland IT and Electronic Engineering Sectors - and Inequalities in Educational Uptake, Belfast: Department for Employment and Learning.

Osborne, R., Miller R., Cormack R. and Williamson, A. (1987). Graduates: Geographical Mobility and Incomes. In Osborne, R., Miller, R. and Cormack, R. (Eds.) Education and Policy in Northern Ireland, Belfast: Policy Research Institute.

Osborne, R. and Murray, R. (1978). Educational Qualifications and Religious Affiliation in Northern Ireland, Belfast: Fair Employment Agency.

Portes, A. and Zhou, M. (1993). The New Second Generation: Segmented Assimilation and Its Variants Among Post-1965 Immigrant Youth, Annals of the American Academy of Political and Social Science, 530, 74-96.

Portes, A. (1998). Social capital: its origins and applications in modern sociology. Annual Review of Sociology, 24, 1-24.

Power, J. and Shuttleworth, I. (1997). Intercensal Population Change in the Belfast Urban Area 1971-91: The Correlates of Population Increase and Decrease in a Divided Society, International Journal of Population geography, 3, 91-108.

Russell, R. (2004). Employment Profiles of Protestants and Catholics: A Decade of Monitoring. In Osborne, B. and Shuttleworth, I. (Eds.) Fair Employment in Northern Ireland: A Generation on. Belfast: Blackstaff Press.

Savage, M., Barlow, J., Dickens, P. and Fielding, T. (1992). Property, Bureaucracy and Culture: Middle-class Formation in Contemporary Britain, London: Routledge.

Sheehan, M. and Tomlinson, M. (1999). The Unequal Unemployed: Discrimination, Unemployment and State Policy in Northern Ireland, Aldershot: Ashgate.

Smith, A. (1993). The Ethnic Sources of Nationalism. In Brown, M. E. (Ed.) Ethnic Conflict and International Security, Princeton: Princeton University Press.

Smith, D. and Chambers, G. (1991). Inequality in Northern Ireland, Oxford: Oxford University Press. 
Standing Advisory Commission on Human Rights (1997) Employment Equality: Building for the Future, London: HMSO. 


\section{Technical ApPendiX}

The Continuous Household Survey (CHS) began in 1983 and samples approximately one percent of households in Northern Ireland each year. It is designed primarily to meet the information needs of government departments in Northern Ireland by providing accurate information on housing, employment, health, education, income and social services etc. The core questions are asked each year but additional modules could change from year to year. The structure of the survey is very much the same as that of the General Household Survey (GHS) used by Cheung and Heath in this volume. We use the CHS 1985/1986 and 2002/2003 as the data for 1985 are the earliest, and that for 2003 the most recent, available from the Data Archive at the time of research for this chapter.

We have conducted careful analysis of whether the overall patterns in 1985 and 1986 and 2002 and 2003, were close enough for us to combine them. The analysis shows that, in terms of both economic activity and class position, the distributions in 1985 were very close to those in 1986, as were the distributions in 2002 and 2003. Detailed data are not presented here but are available from the authors. It is also noted here that there are many respondents in the age range whose religious affiliations are not recorded. For respondents whose own religion is missing but for whom both parents' religions are recorded (both Catholic, or both Protestant, but not otherwise), or who has only one parent with known religion, we have thus coded personal religion as appropriate for the respondent. For respondents with missing religion who do not fall into these two categories, no recoding is done. We feel that this procedure is appropriate in the Northern Ireland context.

The earnings data refer to the total annual gross earnings before deductions from all forms of paid employment. It is noted here that, in the income file for the 1985, no such variable is readily available and considerable time was spent on checking all the available information in the file in order to construct such a variable. The procedure is too complex to report here but all details are available on request. For 1986, 2002 and 2003, the variables (i1b, work, work) are measured as income bands and mid-point values were calculated from the bands. Incremental values for four out of the five last (highest) bands were calculated the mean of which was used for the increment of the highest band where no upper limit is recorded. The constructed earnings variables were put into natural log forms to ensure stability in the modeling procedure. The predicted values from the models were then exponentiated and the figures for the Protestant salariat were set as 100 percent, as shown in Figure 2. We would like to thank Professor Anthony Heath for encouraging us to conduct the analysis on earnings and for suggesting that we use the Protestant salariat's earnings as the basis upon which to make the comparison. 
TABLE 13.1

Proportions of Catholics and Protestants in Northern Ireland (1911-2001)

Column percentages

\begin{tabular}{lccccccccc}
\hline & $\mathbf{1 9 1 1}$ & $\mathbf{1 9 2 6}$ & $\mathbf{1 9 3 7}$ & $\mathbf{1 9 5 1}$ & $\mathbf{1 9 6 1}$ & $\mathbf{1 9 7 1}^{\mathbf{i}}$ & $\mathbf{1 9 8 1}^{\mathbf{i i}}$ & $\mathbf{1 9 9 1}$ & $\mathbf{2 0 0 1}^{\text {iif }}$ \\
\cline { 2 - 9 } & & & & & & & & & \\
Catholic & 34.4 & 33.5 & 33.5 & 34.4 & 34.9 & 31.4 & 28.0 & 38.4 & 40.2 \\
$\begin{array}{l}\text { Other } \\
\text { Denomination }\end{array}$ & 65.4 & 66.3 & 66.3 & 65.2 & 63.2 & 59.2 & 53.5 & 50.6 & 45.9 \\
None & - & - & - & - & - & - & & 3.7 & 313.9 \\
Not stated & 0.2 & 0.2 & 0.2 & 0.4 & 1.9 & 9.4 & 18.5 & 7.3 & 10.0 \\
$\%$ & 100.0 & 100.0 & 100.0 & 100.0 & 100.0 & 100.0 & 100.0 & 100.0 & 100.0 \\
\hline
\end{tabular}

Notes:

1. The 'Other Denomination' category is overwhelmingly Protestant, and we take it as such, but it includes some unspecified Christians and a tiny number of persons of other religions. Other religions amounted to 0.3 percent in 2001.

2. The 1971 and especially the 1981 Censuses were affected by substantial non-response, especially for Catholics.

3. The 2001 Census also inquired about religious background. On that basis the Census Office reports that Catholics account for 43.7 percent of the population and Protestants and other Christians 53.1 percent, with 0.4 percent 'Other religions' and 2.72 percent 'None'.

Sources: The Northern Ireland Census 1991—Religion Report; The Northern Ireland Census 2001—Key Statistics. 
TABLE 13.2A

Educational qualification, by religion and period: Males

Row percentages

\begin{tabular}{|c|c|c|c|c|c|c|}
\hline & $\begin{array}{c}\text { Higher } \\
\text { tertiary }\end{array}$ & $\begin{array}{c}\text { Lower } \\
\text { tertiary }\end{array}$ & $\begin{array}{r}\text { Higher } \\
\text { secondary }\end{array}$ & $\begin{array}{r}\text { Lower } \\
\text { secondary }\end{array}$ & $\begin{array}{r}\text { Primary/ } \\
\text { none }\end{array}$ & $\mathbf{N}$ \\
\hline \multicolumn{7}{|l|}{$1985 / 1986$} \\
\hline Protestant & 6.9 & 17.7 & 17.8 & 10.9 & 46.6 & 2,068 \\
\hline Catholic & 3.7 & 12.6 & 13.8 & 11.3 & 58.7 & 1,422 \\
\hline None & 15.2 & 20.7 & 16.5 & 17.7 & 29.9 & 164 \\
\hline \multicolumn{7}{|l|}{$2002 / 2003$} \\
\hline Protestant & 12.6 & 13.2 & 14.7 & 33.7 & 25.8 & 2,138 \\
\hline Catholic & 12.4 & 10.8 & 15.0 & 35.5 & 26.2 & 1,224 \\
\hline None & 27.7 & 16.1 & 17.5 & 24.1 & 14.6 & 137 \\
\hline
\end{tabular}

TABLE 13.2B

Educational qualification, by religion and period: Females

Row percentages

\begin{tabular}{crrrrrr}
\hline & $\begin{array}{r}\text { Higher } \\
\text { tertiary }\end{array}$ & $\begin{array}{r}\text { Lower } \\
\text { tertiary }\end{array}$ & $\begin{array}{r}\text { Higher } \\
\text { secondary }\end{array}$ & $\begin{array}{r}\text { Lower } \\
\text { secondary }\end{array}$ & $\begin{array}{r}\text { Primary/ } \\
\text { none }\end{array}$ & N \\
\hline $\mathbf{1 9 8 5} / \mathbf{1 9 8 6}$ & & & & & & \\
Protestant & 4.8 & 11.7 & 22.9 & 12.4 & 48.1 & 2,586 \\
Catholic & 3.2 & 10.4 & 17.5 & 12.8 & 56.2 & 1,771 \\
$\quad$ None & 13.3 & 16.4 & 21.9 & 16.4 & 32.0 & 128 \\
$\mathbf{2 0 0 2 / 2 0 0 3}$ & & & & & & \\
Protestant & 12.2 & 11.0 & 12.2 & 40.5 & 24.2 & 2,179 \\
Catholic & 12.3 & 11.7 & 12.0 & 38.9 & 25.0 & 1,653 \\
None & 25.8 & 12.9 & 15.1 & 31.2 & 15.1 & 93 \\
\hline
\end{tabular}


TABLE 13.3A

Economic activity, by religion and period: Males

Row percentages

\begin{tabular}{ccrrrr}
\hline & Active & $\begin{array}{r}\text { Other } \\
\text { inactive }\end{array}$ & $\begin{array}{r}\text { Looking after } \\
\text { home }\end{array}$ & Student & N \\
\hline $\mathbf{1 9 8 5 / 1 9 8 6}$ & & & & & \\
Protestant & 92.1 & 5.5 & 0.2 & 2.2 & 2,190 \\
Catholic & 87.7 & 8.2 & 0.3 & 3.9 & 1,532 \\
None & 87.9 & 4.9 & 1.2 & 6.1 & 165 \\
2002/2003 & & & & & \\
Protestant & 86.0 & 10.7 & 1.0 & 2.3 & 2,166 \\
Catholic & 81.0 & 13.3 & 2.4 & 3.2 & 1,233 \\
None & 78.8 & 11.7 & 0.7 & 8.8 & 137 \\
\hline
\end{tabular}

TABLE 13.3B

Economic activity, by religion and period: Females

Row percentages

\begin{tabular}{ccrrrr}
\hline & Active & $\begin{array}{r}\text { Other } \\
\text { inactive }\end{array}$ & $\begin{array}{r}\text { Looking after } \\
\text { home }\end{array}$ & Student & N \\
\hline $\mathbf{1 9 8 5 / 1 9 8 6}$ & & & & & \\
Protestant & 58.0 & 4.2 & 35.4 & 2.4 & 2,647 \\
Catholic & 47.1 & 4.5 & 46.1 & 2.4 & 1,817 \\
None & 62.3 & 3.1 & 2.7 & 6.9 & 130 \\
2002/2003 & & & & & \\
Protestant & 67.8 & 9.1 & 19.3 & 3.7 & 2,198 \\
Catholic & 60.4 & 10.7 & 24.9 & 4.0 & 1,653 \\
None & 55.2 & 14.6 & 25.0 & 5.2 & 96 \\
\hline
\end{tabular}


TABLE 13.4A

Current occupation (among economically active) by religion and period: Males

Row percentages

\begin{tabular}{|c|c|c|c|c|c|c|c|}
\hline & Salariat & $\begin{array}{r}\text { Routine } \\
\text { non- } \\
\text { manual }\end{array}$ & $\begin{array}{r}\text { Petty } \\
\text { bourgeoisie }\end{array}$ & $\begin{array}{r}\text { Manual } \\
\text { supervisor/ } \\
\text { skilled } \\
\text { manual } \\
\end{array}$ & $\begin{array}{r}\text { Semi- and } \\
\text { unskilled }\end{array}$ & Unemployed & $\overline{\mathbf{N}}$ \\
\hline \multicolumn{8}{|l|}{$1985 / 1986$} \\
\hline Protestant & 24.3 & 9.7 & 11.0 & 26.0 & 13.8 & 15.3 & 2,008 \\
\hline Catholic & 14.5 & 4.5 & 10.2 & 21.3 & 13.1 & 36.4 & 1,342 \\
\hline None & 34.7 & 11.8 & 6.3 & 19.4 & 7.6 & 20.1 & 144 \\
\hline \multicolumn{8}{|l|}{$2002 / 2003$} \\
\hline Protestant & 33.2 & 9.5 & 10.9 & 25.4 & 15.0 & 6.0 & 1,812 \\
\hline Catholic & 30.5 & 7.0 & 11.3 & 25.5 & 17.6 & 8.1 & 967 \\
\hline None & 47.6 & 8.6 & 6.7 & 19.1 & 9.5 & 8.6 & 105 \\
\hline
\end{tabular}

TABLE 13.4B

Current occupation (among economically active) by religion and period: Females

Row percentages

\begin{tabular}{|c|c|c|c|c|c|c|c|}
\hline & Salariat & $\begin{array}{r}\text { Routine } \\
\text { non- } \\
\text { manual }\end{array}$ & $\begin{array}{r}\text { Petty } \\
\text { bourgeoisie }\end{array}$ & $\begin{array}{r}\text { Manual } \\
\text { supervisor/ } \\
\text { skilled } \\
\text { manual } \\
\end{array}$ & $\begin{array}{r}\text { Semi- and } \\
\text { unskilled }\end{array}$ & Unemployed & $\bar{N}$ \\
\hline \multicolumn{8}{|l|}{$1985 / 1986$} \\
\hline Protestant & 22.3 & 29.7 & 2.3 & 2.8 & 32.6 & 10.3 & 1,532 \\
\hline Catholic & 20.5 & 26.0 & 1.5 & 1.2 & 36.3 & 14.5 & 854 \\
\hline None & 40.7 & 25.9 & 2.5 & 1.2 & 17.3 & 12.4 & 81 \\
\hline \multicolumn{8}{|l|}{$2002 / 2003$} \\
\hline Protestant & 34.8 & 31.3 & 3.5 & 4.7 & 22.3 & 3.4 & 1,456 \\
\hline Catholic & 38.9 & 25.6 & 1.7 & 4.5 & 24.4 & 4.8 & 976 \\
\hline None & 46.2 & 19.2 & 1.9 & 3.9 & 21.2 & 7.7 & 52 \\
\hline
\end{tabular}


TABle 13.5A

Avoidance of unemployment: Parameter estimates for men

\begin{tabular}{|c|c|c|c|c|c|c|c|c|c|c|c|c|}
\hline \multirow[b]{3}{*}{ Intercept } & \multicolumn{4}{|c|}{$1985 / 1986$} & \multicolumn{4}{|c|}{$2002 / 2003$} & \multicolumn{4}{|c|}{ Pooled data } \\
\hline & \multicolumn{2}{|c|}{ Model 1} & \multicolumn{2}{|c|}{ Model 2} & \multicolumn{2}{|c|}{ Model 1} & \multicolumn{2}{|c|}{ Model 2} & \multicolumn{2}{|c|}{ Model 1} & \multicolumn{2}{|c|}{ Model 2} \\
\hline & -.48 & $(.51)$ & -.46 & $(.51)$ & .28 & $(.82)$ & .19 & $(.82)$ & .64 & $(.44)$ & .30 & $(.45)$ \\
\hline Catholic & -1.07 & $(.09)$ & -1.10 & (.13) & -.27 & $(.16)$ & -.03 & $(.22)$ & -.87 & $(.08)$ & -1.03 & (.12) \\
\hline None & -.55 & (.23) & -.55 & (.23) & -.41 & (.38) & -.36 & (.38) & -.49 & (.20) & -.49 & (.20) \\
\hline Protestant & 0 & & 0 & & 0 & & 0 & & 0 & & 0 & \\
\hline Age/10 & .94 & (.29) & .94 & (.30) & 1.15 & (.47) & 1.14 & (.47) & .92 & $(.25)$ & .96 & (.25) \\
\hline$(\text { Age } / 10)^{2}$ & -.08 & (.04) & -.08 & (.04) & -.14 & (.06) & -.14 & (.06) & -.08 & (.03) & -.09 & (.03) \\
\hline \multicolumn{13}{|l|}{ Education } \\
\hline Higher tertiary & 1.85 & $(.41)$ & 1.87 & (.41) & .49 & $(.37)$ & .36 & $(.37)$ & 1.27 & (.26) & 1.24 & (.26) \\
\hline Lower tertiary & .65 & (.18) & .66 & (.18) & .45 & $(.38)$ & .39 & $(.38)$ & .58 & (.16) & .57 & (.16) \\
\hline Higher secondary & 0 & & 0 & & 0 & & 0 & & 0 & & 0 & \\
\hline Lower secondary & .54 & (.19) & .52 & (.19) & -.20 & $(.25)$ & -.11 & $(.26)$ & .29 & (.14) & .30 & (.15) \\
\hline Primary/none & -.68 & (.13) & -.70 & (.15) & -1.29 & (.26) & -1.10 & (.28) & -.84 & (.13) & -.79 & (.13) \\
\hline \multicolumn{13}{|l|}{ Marital Status } \\
\hline Married/cohabiting & .22 & $(.12)$ & .22 & $(.12)$ & 1.45 & $(.22)$ & 1.46 & $(.22)$ & .49 & (.10) & .49 & (.10) \\
\hline Divorced/separated & -.92 & (.23) & -.92 & (.23) & .40 & (.34) & .40 & (.34) & -.55 & (.19) & -.55 & (.19) \\
\hline Single & 0 & & 0 & & 0 & & 0 & & 0 & & 0 & \\
\hline \multicolumn{13}{|l|}{ Period } \\
\hline $1985 / 1986$ & & & & & & & & & -1.16 & (.09) & -.81 & (.12) \\
\hline $2002 / 2003$ & & & & & & & & & 0 & & 0 & \\
\hline \multicolumn{13}{|l|}{ Interaction effects } \\
\hline Catholic*qualifications & & & -.02 & $(.08)$ & & & .24 & $(.15)$ & & & .03 & $(.07)$ \\
\hline Catholics*2002/2003 & & & & & & & & & & & .77 & (.18) \\
\hline $\mathrm{N}$ & \multirow{2}{*}{\multicolumn{4}{|c|}{3,314}} & \multicolumn{4}{|c|}{2,939} & \multicolumn{4}{|c|}{6,253} \\
\hline Chi-square (D.F.) & & & & & & & 180 & & 945 & & 968 & \\
\hline
\end{tabular}

Note: Standard errors are given in parentheses; emboldened coefficients are significant at the .05 level or better. 
TABLE 13.5B

Avoidance of unemployment: Parameter estimates for women

\begin{tabular}{|c|c|c|c|c|c|c|c|c|c|c|c|c|}
\hline \multirow{3}{*}{ Intercept } & \multicolumn{4}{|c|}{$1985 / 1986$} & \multicolumn{4}{|c|}{$2002 / 2003$} & \multicolumn{4}{|c|}{ Pooled data } \\
\hline & \multicolumn{2}{|c|}{ Model 1} & \multicolumn{2}{|c|}{ Model 2} & \multicolumn{2}{|c|}{ Model 1} & \multicolumn{2}{|c|}{ Model 2} & \multicolumn{2}{|c|}{ Model 1} & \multicolumn{2}{|c|}{ Model 2} \\
\hline & -.01 & (.73) & $\begin{array}{l}.07 \\
\end{array}$ & (.73) & -.06 & (1.11) & -.08 & $(1.12)$ & .63 & (.64) & .61 & (.64) \\
\hline Catholic & -.22 & $(.14)$ & -.09 & $(.17)$ & -.35 & $(.22)$ & -.31 & $(.24)$ & -.25 & $(.12)$ & -.10 & $(.16)$ \\
\hline None & -.15 & (.38) & -.13 & (.38) & -1.40 & (.57) & -1.37 & (.58) & -.43 & (.32) & -.40 & (.32) \\
\hline Protestant & 0 & & 0 & & 0 & & 0 & & 0 & & 0 & \\
\hline Age/10 & .77 & $(.46)$ & .78 & $(.46)$ & 1.50 & (.67) & 1.51 & (.67) & .99 & $(.38)$ & 1.02 & (.38) \\
\hline$(\text { Age/10 })^{2}$ & -.04 & $(.06)$ & -.04 & $(.06)$ & -.17 & (.09) & -.17 & (.08) & -.07 & $(.05)$ & -.08 & $(.05)$ \\
\hline Higher tertiary & .50 & $(.36)$ & .41 & $(.37)$ & .28 & $(.41)$ & .20 & (.43) & .39 & $(.26)$ & .29 & $(.27)$ \\
\hline Lower tertiary & .24 & $(.25)$ & .18 & (.25) & .52 & (.50) & .48 & (.51) & .31 & $(.22)$ & .25 & (.23) \\
\hline Higher secondary & 0 & & 0 & & 0 & & 0 & & 0 & & 0 & \\
\hline Lower secondary & -.27 & $(.21)$ & -.22 & $(.21)$ & -.15 & $(.31)$ & -.11 & $(.32)$ & -.18 & $(.17)$ & -.13 & $(.17)$ \\
\hline Primary/none & -.61 & (.18) & -.51 & (.19) & -.83 & (.37) & -.76 & (.41) & -.66 & (.16) & -.56 & (.18) \\
\hline \multicolumn{13}{|l|}{ Marital Status } \\
\hline Married/cohabiting & .54 & $(.17)$ & .54 & (.17) & 1.76 & (.35) & 1.76 & (.35) & .77 & (.15) & .77 & (.15) \\
\hline Divorced/separated & -.54 & (.26) & -.55 & (.26) & -.32 & (.34) & -.32 & (.34) & -.52 & (.21) & -.52 & (.21) \\
\hline Single & 0 & & 0 & & 0 & & 0 & & 0 & & 0 & \\
\hline \multicolumn{13}{|l|}{ Period } \\
\hline 1985/1986 & & & & & & & & & -1.03 & $(.14)$ & -1.09 & (.18) \\
\hline $2002 / 2003$ & & & & & & & & & 0 & & 0 & \\
\hline \multicolumn{13}{|l|}{ Interaction effects } \\
\hline Catholic*qualifications & & & .13 & $(.11)$ & & & .08 & $(.17)$ & & & .12 & $(.09)$ \\
\hline Catholic*2002/2003 & & & & & & & & & & & -.14 & $(.25)$ \\
\hline $\mathbf{N}$ & & 2,3 & & & & & & & & 4,9 & & \\
\hline Chi-square (D.F.) & 142 & & 144 & & 111 & & 111 & & 341 & & 343 & \\
\hline
\end{tabular}


Table 13.6A

Access to the salariat: Parameter estimates for men

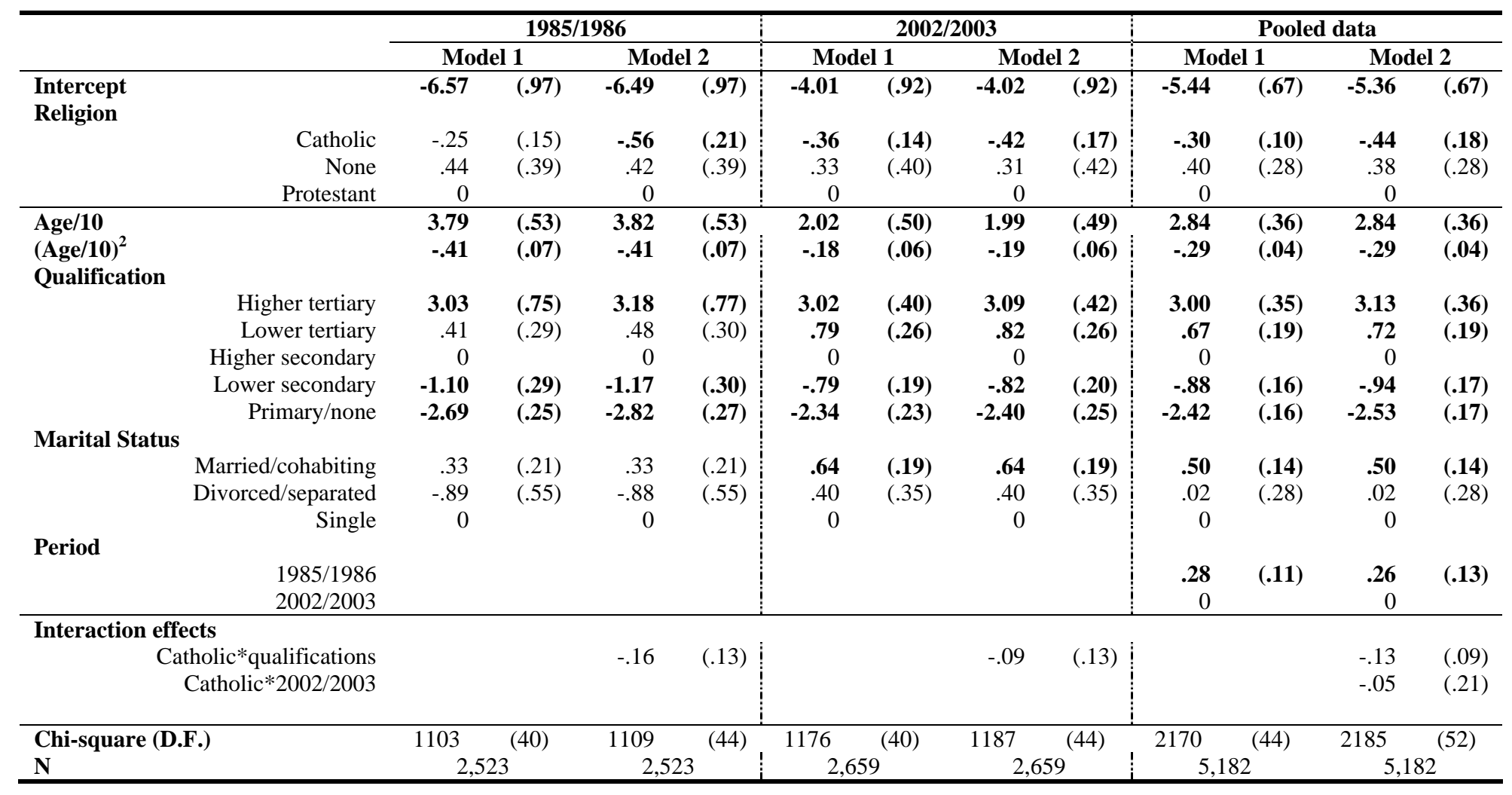


TABle 13.6B

Access to the salariat: Parameter estimates for women

\begin{tabular}{|c|c|c|c|c|c|c|c|c|c|c|c|c|c|}
\hline \multirow{3}{*}{\multicolumn{2}{|c|}{$\begin{array}{l}\text { Intercept } \\
\text { Religion }\end{array}$}} & \multicolumn{4}{|c|}{$1985 / 1986$} & \multicolumn{4}{|c|}{$2002 / 2003$} & \multicolumn{4}{|c|}{ Pooled data } \\
\hline & & \multicolumn{2}{|c|}{ Model 1} & \multicolumn{2}{|c|}{ Model 2} & \multicolumn{2}{|c|}{ Model 1} & \multicolumn{2}{|c|}{ Model 2} & \multicolumn{2}{|c|}{ Model 1} & \multicolumn{2}{|c|}{ Model 2} \\
\hline & & -6.35 & (1.03) & -6.39 & (1.01) & -3.22 & (.90) & -3.40 & $(.91)$ & -4.22 & (.66) & -4.33 & (.67) \\
\hline & Catholic & -.21 & $(.16)$ & -.15 & $(.18)$ & -.11 & $(.13)$ & .14 & $(.17)$ & -.16 & $(.10)$ & -.04 & $(.17)$ \\
\hline & None & .73 & $(.45)$ & .73 & (.44) & .09 & $(.48)$ & $\begin{array}{l}.17 \\
-.05\end{array}$ & $(.48)$ & .48 & $(.32)$ & .49 & $(.32)$ \\
\hline & Protestant & 0 & & 0 & & 0 & & 0 & & 0 & & 0 & \\
\hline Age/10 & & 3.57 & (.58) & 3.58 & (.58) & 1.87 & (.50) & 1.91 & (.50) & 2.50 & (.37) & 2.51 & (.37) \\
\hline$\left(\right.$ Age/10) ${ }^{2}$ & & -.43 & (.07) & -.43 & (.07) & -.19 & (.06) & -.19 & (.06) & -.28 & (.05) & -.29 & (.05) \\
\hline \multicolumn{14}{|l|}{ Qualification } \\
\hline & Higher tertiary & 3.16 & (.49) & 3.07 & (.49) & 2.92 & $(.38)$ & 2.72 & (.39) & 3.02 & $(.30)$ & 2.88 & (.30) \\
\hline & Lower tertiary & 1.57 & (.23) & 1.51 & (.23) & 1.30 & (.27) & 1.18 & (.27) & 1.41 & (.17) & 1.32 & (.17) \\
\hline & Higher secondary & 0 & & 0 & & 0 & & 0 & & 0 & & 0 & \\
\hline & Lower secondary & -.77 & (.27) & -.71 & (.27) & -1.22 & $(.21)$ & -1.08 & $(.21)$ & -1.03 & (.15) & -.94 & (.16) \\
\hline & Primary/none & -2.86 & (.23) & -2.76 & (.24) & -2.93 & (.27) & -2.68 & (.29) & -2.89 & (.17) & -2.75 & (.18) \\
\hline \multicolumn{14}{|l|}{ Marital Status } \\
\hline & Married/cohabiting & -.38 & $(.22)$ & -.38 & $(.22)$ & .05 & $(.19)$ & .04 & $(.19)$ & -.13 & $(.14)$ & -.13 & $(.14)$ \\
\hline & Divorced/separated & -.17 & (.36) & -.18 & (.36) & -.21 & (.27) & -.21 & (.27) & -.20 & $(.21)$ & -.20 & $(.21)$ \\
\hline & Single & 0 & & 0 & & 0 & & 0 & & 0 & & 0 & \\
\hline \multicolumn{14}{|l|}{ Period } \\
\hline & $1985 / 1986$ & & & & & & & & & -.37 & (.11) & -.34 & $(.13)$ \\
\hline & $2002 / 2003$ & & & & & & & & & 0 & & 0 & \\
\hline \multicolumn{14}{|c|}{ Interaction effects } \\
\hline Cat & tholic qualifications & & & .16 & $(.14)$ & & & .32 & (.14) & & & .22 & (.09) \\
\hline Cath & holics in 2002/2003 & & & & & & & & & & & .08 & $(.21)$ \\
\hline Chi-square (D.F & & 1525 & $(40)$ & 1533 & (44) & 1098 & (40) & 1107 & (44) & 2659 & (44) & 2677 & (52) \\
\hline $\mathbf{N}$ & & \multicolumn{2}{|c|}{2,107} & \multicolumn{2}{|c|}{2,107} & \multicolumn{2}{|c|}{2,365} & \multicolumn{2}{|c|}{2,365} & & & \multicolumn{2}{|c|}{4,472} \\
\hline
\end{tabular}


FIGURE 13.1A

Predicted probabilities of access to the salariat, by educational level: Males

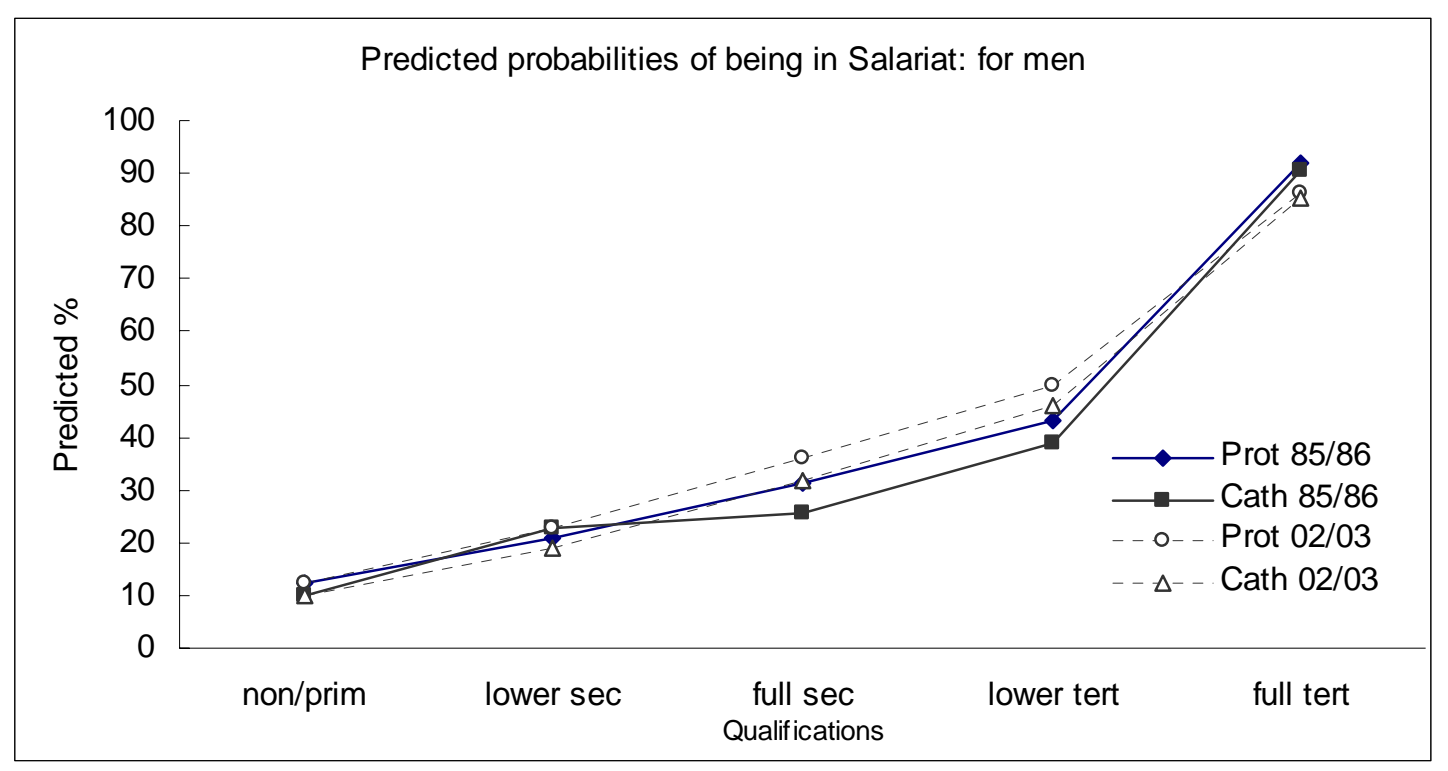


FIGURE 13.1B

Predicted probabilities of access to the salariat, by educational level: Females

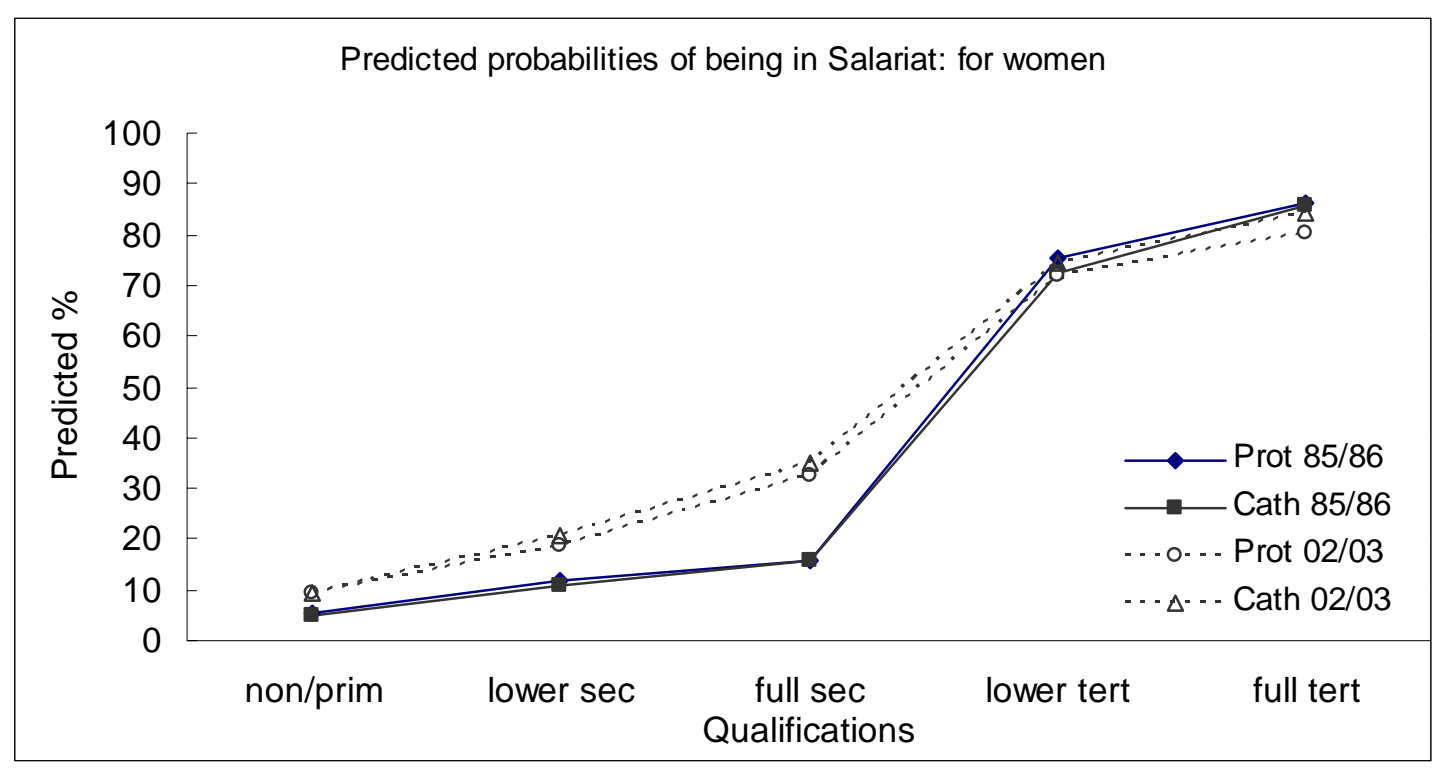


FIGURE 13.2A

Predicted annual gross earnings from paid employment: Males

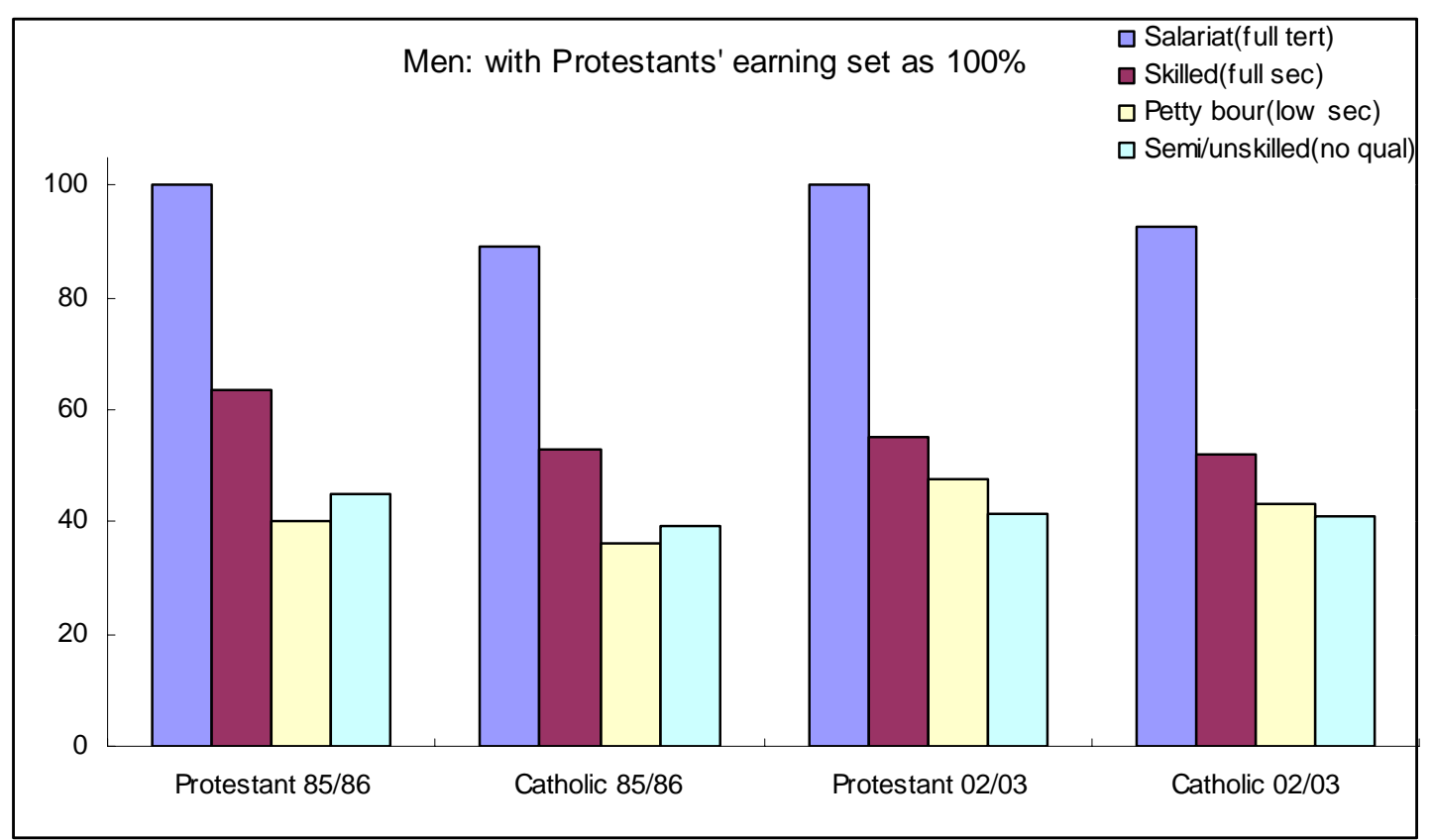

Note: Based on predicted values controlling for class, education, religion, age, age squared and marital status.

Source: The income files from the CHS 1985, 1986, 2002 and 2003. 
FIGURE 13.2B

Predicted annual gross earnings from paid employment: Females

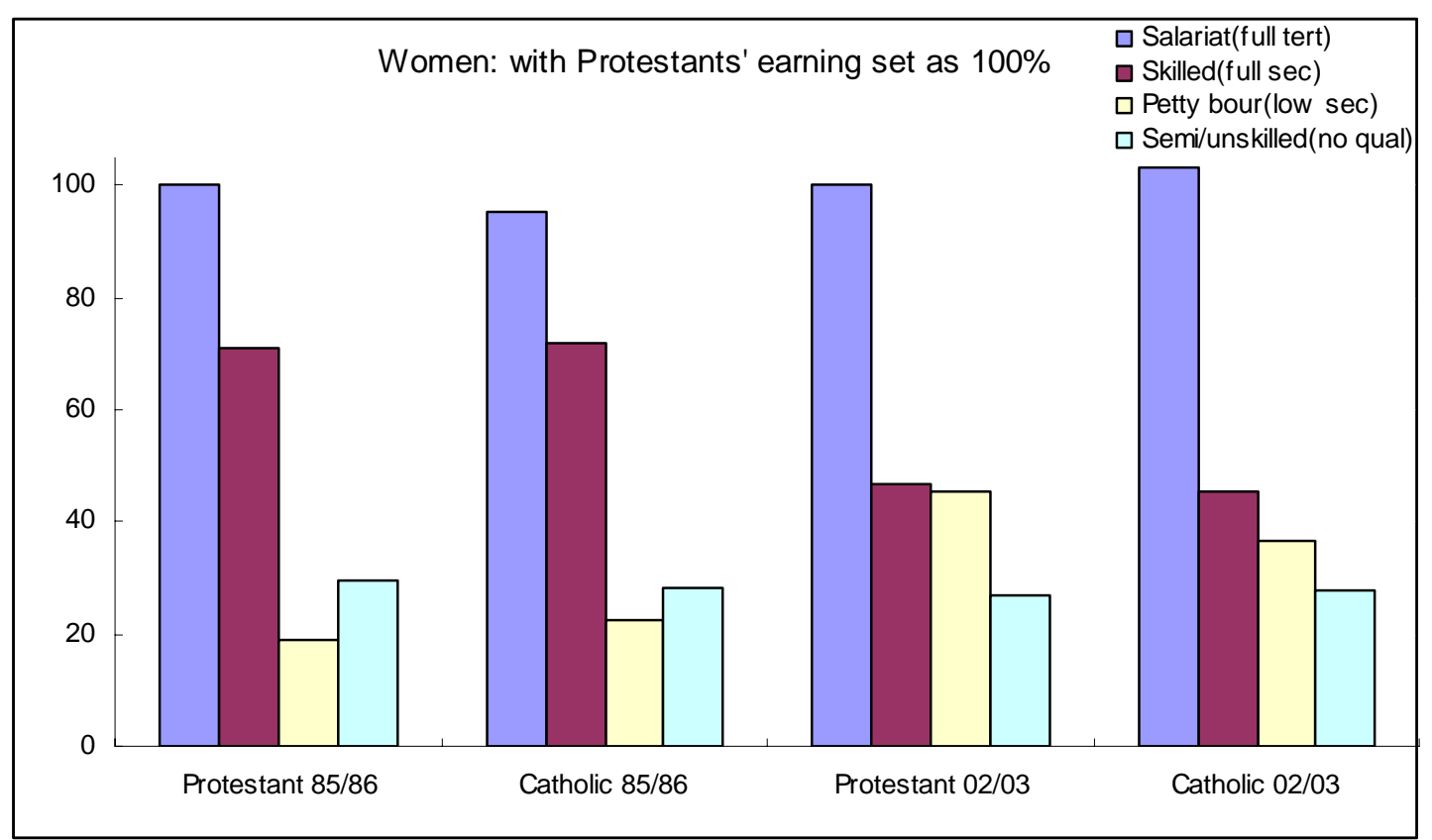

Note: Based on predicted values controlling for class, education, religion, age, age squared and marital status.

Source: The income files from the CHS 1985, 1986, 2002 and 2003. 


\section{APPENDIX}

TABLE 13A.1

Multinomial logit regression of occupational destinations (contrasts with semi and unskilled work)

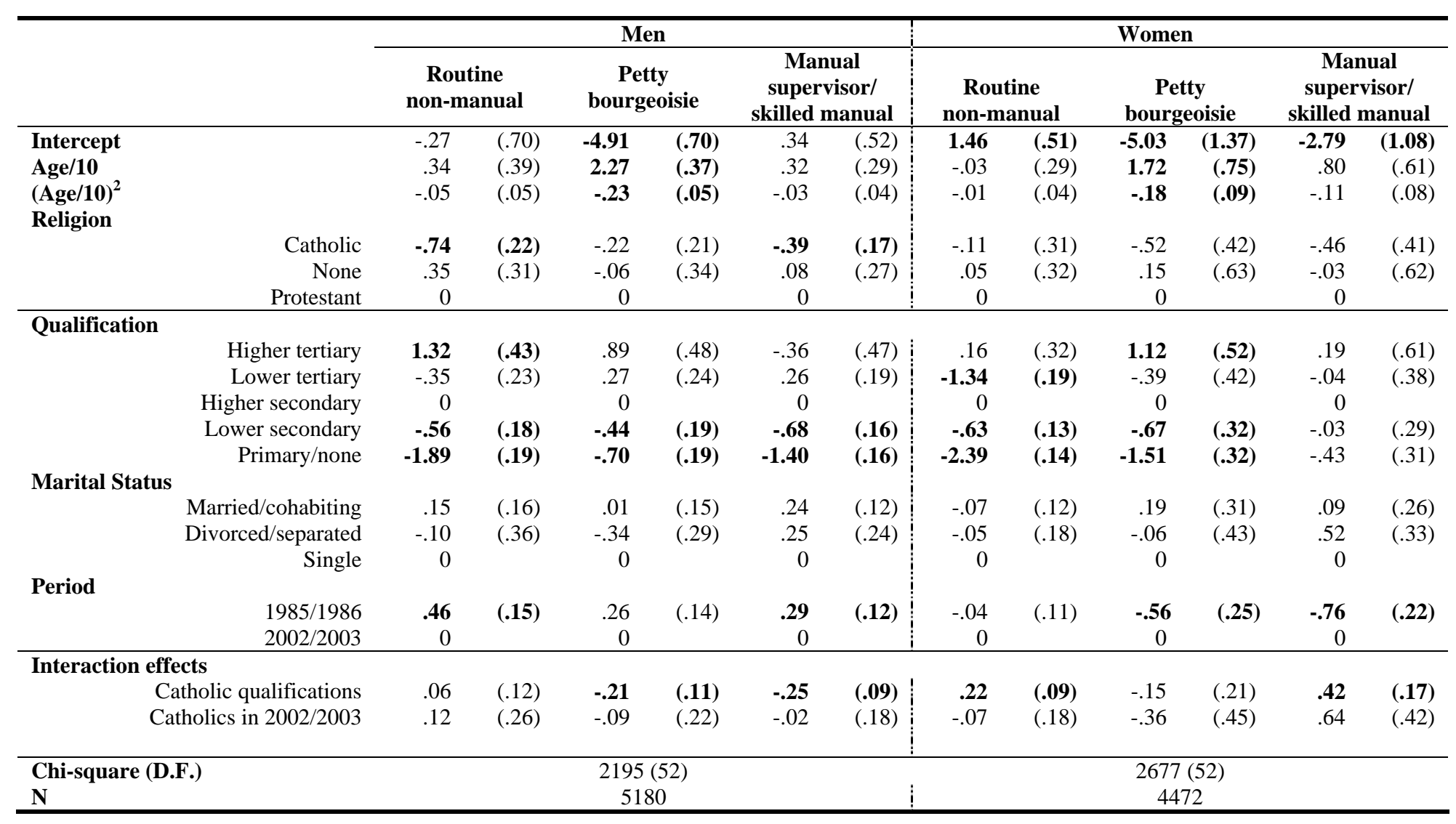

